\title{
IPO Valuation of a Tourism-Gaming Company in China
}

\author{
$\underline{\text { C. Lim }}^{\text {a }}$ and D. Cheung ${ }^{b}$ \\ ${ }^{a}$ Nanyang Business School \& Fellow of the Institute on Asian Consumer Insight, Nanyang Technological \\ University, Singapore \\ ${ }^{b}$ Waikato Management School, University of Waikato, New Zealand \\ Email: christinelim@ntu.edu.sg
}

\begin{abstract}
China has enjoyed increasing economic prosperity since the Open Door Policy was implemented in the 1980s. The rapid economic expansion has led to tourism investment in China. The tourism and hospitality industry covers a wide range of businesses. Sectors include accommodation, food and beverage, meeting and events, gaming, entertainment and recreation, and tourism services. Tourism companies seeking capital to expand their operation for future growth, may list on a stock exchange and offer/issue new shares to the public. The latter is known as initial public offering.

In this paper, we will use a case study approach to examine the global initial public offering (IPO) of Wynn Macau Limited. Macau, the former Portuguese colony, is China's gambling capital. It is the largest gambling market in the world and the only place to gamble legally in China. Macau is located on the Pearl River Delta on the southern coastline of China's Guangdong Province. The latter is China's wealthiest, most urban and populous province. About $80 \%$ of Macau's revenue comes from mass-market gambling. The Mainland Chinese is the main source of Macau's visitors, accounting for more than 50\% of arrivals. It also attracts tourists from Taiwan, Japan, Korea, Thailand, Malaysia, Singapore, Indonesia and the Philippines, which are all located within an approximate four-hour flight from Macau.
\end{abstract}

Gambling or gaming generates travel and it is seen as a tourism offering by the gaming-entertainment industry. In some countries, it has become the major force in the tourism industry. After the 1999 handover to China, the Chinese Government took a strategic decision to develop Macau into Asia's premier gambling destination. In 2002, the gambling monopoly of Stanley Ho was dismantled and gambling licences were issued to foreign operators like Mr Adelson (who opened the Sands Macao) and Mr Wynn. Since the liberalization of the gaming industry in 2002, there has been a drastic increase in the number of gaming operators and casino properties in Macau.

Wynn Resort Macau ("WRM") was established in 2001 to enter the Macau hotel casino gaming business. WRM, being one of the three concessionaries in Macau, will have its concession period expire in June 2022. In July 2004, WRM signed a land concession contract with the Macau government for 16 acres of land for an initial term of 25 years, subject to renewal condition. Wynn Macau, Limited was incorporated as a limited liability company in the Cayman Islands on 4 September 2009. It is the holding company of WRM, and a casino resort which comprises a casino of approximately 205,000 square feet, 600 luxury rooms and suites, five restaurants, retail promenade of 46,000 square feet featuring high-end, brand-name retail stores in Macau. Wynn Macau, Limited was listed on the Hong Kong Stock Exchange on 9 October 2009.

The global offering in September 2009 consisted of the Hong Kong public offer and international offer of 1,250 million ordinary shares. Additionally, the offer price was set between HK\$8.52 and HK\$10.08 per offer share. The global offering was fully underwritten by joint bookrunners. Assuming no exercise of overallotment, the 1,250 million shares issued in the global offering would represent $25 \%$ of the enlarged share capital (which is 5 billion shares in total) immediately after the completion of the global offering (Wynn Macau, Limited IPO prospectus, 2009). The purpose of this paper is to undertake a valuation of Wynn Macau Limited at the time of the IPO to evaluate the offering price and whether the new share issues have been a good investment. A description of the offering precedes the discussion of the valuation methods used, which include the discounted free cash flows approach and the terminal value of the firm estimation.

Keywords: Tourism-gaming; Wynn Macau; initial public offering; terminal value 


\section{INTRODUCTION}

China has enjoyed increasing economic prosperity since the Open Door Policy was implemented in the 1980s. The rapid economic expansion has led to tourism investment in China. The tourism and hospitality industry covers a wide range of businesses. Sectors include accommodation, food and beverage, meeting and events, gaming, entertainment and recreation, and tourism services. Tourism companies seeking capital to expand their operation for future growth, may list on a stock exchange and offer/issue new shares to the public. The latter is known as initial public offering. In this paper, we will use a case study approach to examine the global initial public offering (IPO) of Wynn Macau Limited.

Tourist attractions are essential pull-factor for destination. Pearce (1991) as cited in Smith and Hinch (1996) defines a tourist attraction as "a named site with a specific human or natural feature which is the focus of visitor and management attention" (p. 46). If people travel to participate in casino gambling, casinos can be considered as tourist attractions and they are seen as a tourism offering by the gaming-entertainment industry. In some countries, gaming has become the major force in the tourism industry. Macau is a classic example in which casinos constitute major tourist attractions and its tourism industry is overly dependent on gambling.

Macau, the former Portuguese colony, is China's gambling capital. It is the largest gambling destination in the world and the only place to gamble legally in China. Since Hong Kong and China do not permit legalized casino gambling, the non-competitive environment has ensured Macau's comparative advantage in terms of casino gambling within China. Another advantage which has benefitted the gaming industry is Macau's geographical location. Located at the mouth of the Pearl River delta on the southern coastline of China's Guangdong Province, Macau is in close proximity to the wealthy, urban and populous provinces in Eastern and Southern China. Like Hong Kong, it became a Special Administrative Region (SAR) within the People's Republic of China on 20 December 1999. As a former Portuguese trading centre, Macau was a conduit for China, re-exporting textiles and garments (Hobson, 1995). Since the signing of the Sino-Portuguese sovereignty agreement in 1987 (which would see the return of Macau to Chinese administration in 1999), Macau has rapidly transformed from a trading to a tourism centre with the tourism-gaming industry taking prominence in its economy.

After the 1999 handover to China, the Chinese Government took a strategic decision to develop Macau into Asia's premier gambling destination. In 2002, Stanley Ho's monopoly on the casino industry was dismantled by the Macau SAR Government in an attempt to end the gambling monopoly, and to modernize the tourism-gaming industry (Gu, 2004). Besides awarding license to Stanley Ho's Sociedade de Jogos de Macau (SJM), gambling licences were also issued to two US gaming companies, Las Vegas Sands Inc and Wynn Resorts Inc, owned by Las Vegas gaming moguls Sheldon Adelson and Steve Wynn, respectively. The introduction of competition into Macau's gaming industry has forced the casinos to enhance their management skills and customer services, and to pursue economies of scale by adopting clustering strategy.

Since the gaming industry was liberalized in 2002, there has been a drastic increase in the number of gaming operators and casino properties in Macau. Unlike Las Vegas' gaming industry, Macau casinos do not rely heavily on non-gaming tourism facilities, attractions or services such as entertainment, convention, shopping and recreation. The economic significance of gambling is evident in Macau as about $80 \%$ of its revenue comes from mass-market gambling. The Mainland Chinese is the main source of Macau's visitors, accounting for more than $50 \%$ of arrivals. It also attracts tourists from Taiwan, Japan, Korea, Thailand, Malaysia, Singapore, Indonesia and the Philippines, which are all located within an approximate four-hour flight from Macau.

\section{WYNN MACAU IPO}

Wynn Resort Macau ("WRM") was established in 2001 to enter the Macau hotel casino gaming business. WRM, being one of the three concessionaries in Macau, will have its concession period expire in June 2022. In July 2004, WRM signed a land concession contract with the Macau government for 16 acres of land for an initial term of 25 years, subject to renewal condition. Wynn Macau, Limited was incorporated as a limited liability company in the Cayman Islands on 4 September 2009. It is the holding company of WRM, and a casino resort which comprises a casino of approximately 205,000 square feet, 600 luxury rooms and suites, five restaurants, retail promenade of 46,000 square feet featuring high-end, brand-name retail stores in Macau. Wynn Macau, Limited was listed on the Hong Kong Stock Exchange on 9 October 2009. The global offering in September 2009 consisted of the Hong Kong public offer and international offer of 1,250 million ordinary shares. Additionally, the offer price was set between HK\$8.52 and HK\$10.08 per offer share. The IPO proceeds raised would be used 
mainly to repay the acquisition note to its immediate holding company, WM Cayman Holdings I. The global offering was fully underwritten by joint bookrunners. Assuming no exercise of overallotment, the 1,250 million shares issued in the global offering would represent $25 \%$ of the enlarged share capital (which is 5 billion shares in total) immediately after the completion of the global offering (Wynn Macau, Limited IPO prospectus, 2009).

Going public involves some real costs. There are one-time direct and indirect costs (such as legal, accounting and investment banking fees) as well as on-going costs associated with being a publicly-listed company. Some of the drawbacks of being a publicly-traded firm include the degree of disclosure and scrutiny that may be deemed troublesome, investor participation can affect stock price level and volatility in a firm's shareholder base, exposing management to uncertainty and loss of company control due to shareholder intervention in management decisions, limit on management freedom to act, thereby affecting the manager's perceived decision-making autonomy and curtailing managerial inputs (Lerner, et al., 2009; Kleeburg, 2005).

IPOs are often seen as risky investment products as they have only been available to the public for a short time and there is little historical information to analyse the companies (or issuers). Since investors know little about IPOs than the existing traded stocks, and without the previous trading prices as benchmarks, Chang, et al. (2008) explain that investors are more cautious when investing in IPOs. Hence, IPOs are generally underpriced to attract investors to purchase the stocks. IPO underpricing can represent a significant cost to the firms going public. (Canina, et al., 2008; Luo, 2008). The IPO underpricing phenomenon is well documented, especially in the finance literature. Most past studies examined the after-market performance of IPOs immediately after listing.

The purpose of this paper is to undertake a valuation of Wynn Macau Limited at the time of the IPO to evaluate the offering price and whether the new share issues have been a good investment. The valuation methods include the discounted free cash flows approach and the estimation of the firm's terminal value.

\section{VALUATION METHOD}

\subsection{Weighted Average Cost of Capital Estimation}

If a firm uses both debt and equity to finance its investments, the cost of capital is a weighted cost of each. Hence, the weighted average cost of capital (WACC) is a weighting of its costs of equity $\left(R_{S}\right)$ and costs of debt $\left(\mathrm{R}_{\mathrm{B}}\right)$, as shown below:

$$
R_{W A C C}=\frac{B}{S+B}\left(\mathrm{R}_{\mathrm{B}}\right)(1-T C)+\frac{S}{S+B}\left(R_{S}\right)
$$

Based on the audited financial statements of Wynn Macau for the year ended 31 December 2008 (see page IA-5 Wynn Macau IPO prospectus, 2009), the equity is $\mathrm{HK} \$ 737,505,000$ and long-term borrowings are HK\$ 7,972,912,000. The weights for equity and debt are given as follows:

$$
\begin{gathered}
\frac{S}{S+B}=\frac{737,505,000}{737,505,000+7,972,912,000}=0.08 \\
\frac{B}{S+B}=\frac{7,972,912,000}{737,505,000+7,972,912,000}=0.92
\end{gathered}
$$

In 2008, the effective tax rate (Tc) of Macau represented the special gaming tax of $35 \%$. Cost of debt $\left(R_{B}\right)$ is the effective interest rate for Wynn Macau which has borrowings denominated in Hong Kong dollars and United States dollars, bearing interest at Hong Kong Interbank Offered Rate (HIBOR) plus $1.75 \%$ and London Interbank Offered Rate (LIBOR) plus $1.75 \%$, respectively. [For detailed discussion on interest rate risk and sensitivity, see Wynn Macau IPO Prospectus (2009) Appendix 1A-23 and 1A-47]. Although the company under the interest rate swap arrangement, paid fixed interest payment for certain variable interest bearing borrowings, the related borrowings accounted for approximately $27 \%$ of the total borrowings. For simplicity, without taking into account the interest rate swap, we have calculated the weighted average of the borrowings denominated in Hong Kong dollars and United States dollars using the average 1-year HIBOR and LIBOR plus $1.75 \%$. Hence, the weighted average cost of debt is $5.62 \%$ (see Appendices 1 and 2).

Using the Capital Asset Pricing Model (CAPM), an expected return on Wynn Macau can be estimated as follows:

Return of equity $=R_{S}=\bar{R}=R_{F}+\beta\left(\overline{R_{M}}-R_{F}\right)$ 
Wynn Macau's beta $(\beta)$ is not available due to its unlisted status in 2008 . However, there is only one comparable company, SJM Holdings Limited, which is engaged in hotel and gaming business in Macau and it is also listed on the Hong Kong stock market. Its beta of 0.76 in 2008 is used a proxy for Wynn Macau. The risk free rate $\left(R_{F}\right)$ is $1.83 \%$ which is an average rate of 1 -year US Treasury Bill in $2008 ; \overline{R_{M}}$ represents the expected return on the market, that is, a return on the Hong Kong stock market. The Hang Seng Index, which represents the barometer of the Hong Kong stock market to measure the overall market performance in Hong Kong, has been used to calculate the market return (HKEx Fact Book (2005-2008). It is estimated that the average market return for the last three years is approximately $15 \%$ (see Appendix 3).

Based on equations (1) and (2), the return of equity and WACC are computed:

$$
\begin{aligned}
& R_{S}=1.83 \%+0.76(15 \%-1.83 \%)=11.84 \% \\
& R_{W A C C}=0.08(11.84 \%)+0.92(5.62 \%)(1-35 \%)=4.31 \%
\end{aligned}
$$

\subsection{Free Cash Flow to the Firm method}

Free Cash Flow to the Firm (FCFF) is the amount of cash flows available to all claimants to the firm, including holders of common stocks, preferred stocks, bonds and lenders (Stefano \& Stefano, 2004). It is calculated as follows:

$\mathrm{FCFF}=$ EBIT $(1-\mathrm{t})+$ Depreciation - Capital expenditure $+/$ - change in working capital

Step 1 - The computation of FCFF for Wynn Macau based on the management's forecast, is given below:

In thousand $(\mathrm{HK} \$)$

Year

EBITDA

Depreciation \& Amortisation

EBIT

EBIT (1-t)

Depreciation \& Amortisation

Capital expenditure

Change in net working capital

FCFF

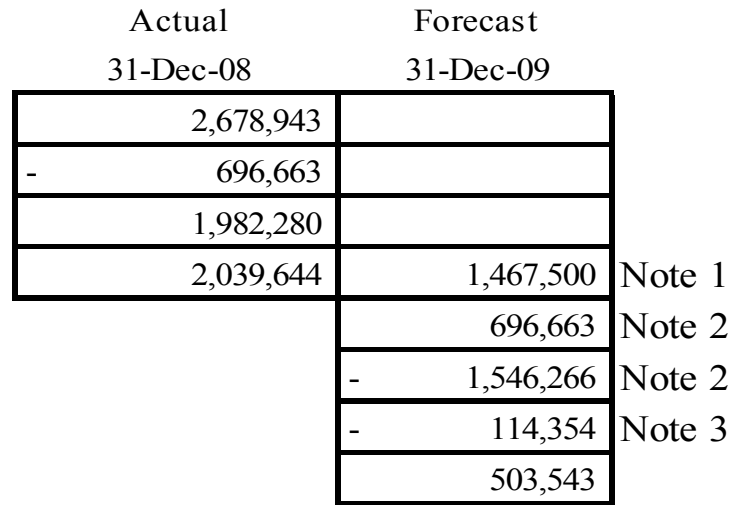

Note 1 - Forecast net income

According to the profit forecast set out in the prospectus, the management expected the forecast consolidated net profit attributable to equity holders of the company for the year ended 31 December 2009 to be no less than HK\$ 1,467.5 million (Wynn Macau Limited IPO prospectus, 2009). When compared to the actual performance in 2008 , the forecast may seem conservative. The company has achieved operating profit attributable to the equity holders of the company of HK\$2,039,644 in 2008.

Note 2 - Forecast capital expenditure and depreciation and amortisation

Wynn Macau has been spending substantial amount in hotel construction and land acquisition. In 2006 and 2007 , capital expenditures on the purchase of property and equipment of HK\$3,038 million and HK\$2,210 million, respectively, have been incurred. Although the company did not provide any indication of capital expenditure for the following years, the additions to property and equipment of HK\$ 1,546.3 million have been taken into account for 2008 .

Note 3 - Change in net working capital

Net working capital is defined as the difference between current assets and current liabilities (Ross, Westerfield, \& Jaffe, 2010). 
Lim and Cheung, IPO Valuation of a Tourism-Gaming Company in China

Step 2 - Discounting the FCFF with an appropriate discount rate (i.e. WACC) and reasonable growth rate.

Since 2006, Wynn Macau has been expanding its business to increase gaming space, restaurants and retail amenities. In 2009, it was expected to provide 600 hotel rooms and suites, retail outlets and the casino. Moreover, keen competition in the operation of casino hotel resorts in Macau has intensified since the concessionaries were granted in 2002.

An average growth rate of $3.2 \%$ is used for the following reasons. While the management of Wynn Macau has anticipated growth in their business, the latter is not specified in the prospectus. GDP growth rate for Macau was $12.9 \%$ in 2008 . Given the volatility of the gaming industry based on risk factors which include the support from the PRC government and keen competition, we have used one quarter of Macau's GDP growth rate in 2008 as a proxy for the growth rate in the company earnings for Wynn Macau. Hence, the estimated terminal value of the firm is given as:

$$
\begin{aligned}
\text { Value of firm } & =\frac{\mathrm{FCFF}}{\mathrm{R}_{\mathrm{WACC}}-\mathrm{g}} \\
& =\frac{503,543,000}{0.0431-0.032} \\
& =45,364,234,000
\end{aligned}
$$

Value per share of Wynn Macau using the FCFF method:

$=$ Value of firm / total number of shares

$=\mathrm{HK} \$ 45,364,234,000 / 5,000,000,000$

$=$ HK $\$ 9.07$

Based on the mid-price of HK\$9.30, we would recommend the new share issues of Wynn Macau to international investors. Further support on the recommendation is based on Wynn Macau's profitability as explained in the next section.

\section{CONCLUDING REMARKS}

Wynn Macau has a price/earning $(\mathrm{P} / \mathrm{E})$ ratio of 22.8 which is lower than the industry average of 34.8. An expected price based on the industry $\mathrm{P} / \mathrm{E}$ ratio would be the industry $\mathrm{P} / \mathrm{E}$ ratio multiplied by the company earnings per share. In other words, the offer price can be computed as $34.8 * 0.408$ which is approximately HK $\$ 14.2$ per share. The range of the offer price between HK\$ 8.52 and HK $\$ 10.08$ as proposed by the management may suggest that the share is likely to be underpriced. Apart from $\mathrm{P} / \mathrm{E}$ ratio, price relative to tangible assets and revenue of 6.59 and 3.16, respectively, are also higher than the industry norms of 1.47 and 1.94 , respectively.

\begin{tabular}{|lcc|}
\hline & $\begin{array}{c}\text { Wynn Macau } \\
\text { Actual res ults }\end{array}$ & Indus try \\
Ratio & $\mathbf{( 2 0 0 8 )}$ & \\
Price / earning ratio & 22.80 & 34.83 \\
Price / tangible assets & 6.59 & 1.47 \\
Price/revenue & 3.16 & 1.94 \\
Return on equity & 2.66 & 0.09 \\
Return on assets & 0.18 & 0.10 \\
\hline
\end{tabular}


For the year ended 31 December 2009, the net profit attributable to the equity holders of the company was $41 \%$ higher than the forecast amount. This also shows that the profitability of the gaming and hotel sector in Macau was better than expected in 2009.

The upward surge of the share price of Wynn Macau since its IPO in September 2009 is attributed to its actual (audited) financial results and dividend payout in 2009. The average share price for the period 1 October 2009 to 31 December 2009 is HK\$10 compared to the final offer share price of HK\$10.08. The share prices continued to increase in 2010 and reached an average of HK\$11.19 by July 2010.

\section{ACKNOWLEDGMENTS}

The authors would like to thank the anonymous reviewers for helpful comments and suggestions. The first author is grateful to the Nanyang Business School, Nanyang Technological University for financial support.

\section{REFERENCES}

British Bankers' Association (2008). Retrieved from http://www.bbalibor.com/bba/jsp/polopoly.jsp?d=1661\&a=15812\&artpage=all. Accessed 26 November 2010.

Canina, L., Chang, C. \& Gibson, S. (2008). IPO Underpricing in the Hospitality Industry: A Necessary Evil? Journal of Hospitality Financial Management, 16(2), 33-54.

Chang, E., Chen, C., Chi, J. \& Young, M. (2008). IPO Pricing in China: New Evidence from the Primary and Secondary Markets. Emerging Markets Review, 9, 1-16.

Gu, Z. (2004). Macau Gaming: copying the Las Vegas style or creating a Macau model? Asia Pacific Journal of Tourism Research, 9(1), 89-96.

HKEx Fact Book (2005-2008). Retrieved from http://www.hkex.com.hk/eng/stat/statrpt/factbook2006/fb2006.htm. Accessed 26 November 2010.

Hobson, P. (1995). Macau: gambling on its future? Tourism Management, 16(3), 237-246.

Hong Kong Monetary Authority (2008). Retrieved from http://www.info.gov.hk/hkma/index.htm. Accessed 26 November 2010.

Kleeburg, R.P. (2005). Initial Public Offerings. Mason, Ohio: Thomson.

Lerner, J., Hardymon, F. \& Leamon, A. (2009). Venture Capital and Private Equity, $4^{\text {th }}$ edition. John Wiley \& Sons, Inc: New Jersey, USA.

Luo, X. (2008).When Marketing Strategy First Meets Wall Street: Marketing Spendings, and Firms' Initial Public Offerings. Journal of Marketing, 72(5), 98-109.

Ross, S. A., Westerfield, R., \& Jaffe, J. F. (2010). Corporate Finance (9th ed.): Boston : McGraw-Hill/Irwin.

Smith, G.J. \& Hinch, T.D. (1996). Canadian Casinos as Tourist Attractions: Chasing the Pot of Gold. Journal of Travel Research, 34(3), 37-45.

Stefano, C., \& Stefano, G. (2004). Venture capital: A Euro-system approach. Berlin Heidelbery New York: Springer-Verlag.

Wynn Macau, Limited IPO prospectus. (2009). Retrieved from http://www.hkexnews.hk/listedco/listconews/sehk/20090924/LTN20090924064.PDF

Accessed 5 November 2010. 
Lim and Cheung, IPO Valuation of a Tourism-Gaming Company in China

\section{APPENDICES}

1. Average of 12 -month LIBOR for 2008

\begin{tabular}{lcc} 
& 12-month LIBOR & 12-month HIBOR \\
January & 4.89 & 2.80 \\
Februry & 4.81 & 2.17 \\
March & 4.80 & 1.89 \\
April & 4.74 & 2.12 \\
May & 5.04 & 2.38 \\
June & 5.49 & 2.99 \\
July & 5.31 & 2.90 \\
August & 5.11 & 2.80 \\
September & 4.81 & 2.88 \\
October & 3.74 & 3.57 \\
November & 2.12 & 2.44 \\
December & 1.36 & 2.15 \\
\cline { 2 - 3 } & 4.35 & 2.59 \\
\hline
\end{tabular}

Sources: British Bankers' Association (2008) for LIBOR and Hong Kong Monetary Authority (2008) for HIBOR.

2. Calculation of weighted average borrowing rates using HIBOR and LIBOR for the year of 2008 based on the borrowing level

\begin{tabular}{|c|c|c|c|c|}
\hline Borrowings as at 31 December 20008 & $\underline{\mathrm{HK}} \$^{\prime} 000$ & $\underline{\text { Terms }}$ & $\underline{\text { Interest }}$ & Weighted \\
\hline & & & $\underline{\text { rate }}$ & $\underline{\text { average }}$ \\
\hline Denominated in $\mathrm{HK} \$$ & $5,933,850$ & HIBOR $+1.75 \%$ & 6.10 & 4.43 \\
\hline Denominated in US\$ & $2,241,659$ & LIBOR $+1.75 \%$ & 4.34 & 1.19 \\
\hline & $8,175,509$ & & & 5.62 \\
\hline
\end{tabular}

3. Calculation of market returns using the Hang Seng Index for the three years from 2006 to 2008

\begin{tabular}{lcc} 
Year & Average & Yearly return \\
\cline { 2 - 3 } 2005 & $14,352.59$ & \\
2006 & $16,880.22$ & $18 \%$ \\
2007 & $23,180.39$ & $37 \%$ \\
2008 & $20,884.09$ & $-10 \%$ \\
Average return & & $15 \%$ \\
\hline
\end{tabular}

Source: HKEx Fact Book (2005-2008). 